\title{
Redesign of Al-Murqoniyah Vocational High School, Hambalang (Case Study: SMK Al-Murqoniyah, Hambalang)
}

\author{
Era Agita Kabdiyono ${ }^{1}$ \\ \{era.agita.k@undira.ac.id ${ }^{1}$ \} \\ Department of Civil Engineering, Faculty of Engineering and Informatics, University Dian Nusantara, \\ West Jakarta, Jakarta, Indonesia ${ }^{1}$
}

\begin{abstract}
The purpose of this research is to redesign the structure of the school building of the Al-Murqoniyah Vocational High School using the code SNI 1726-2012 and SNI 2847-2013. It will be planned with 2-storey using bearers moment frame system with structural modeling using 3dimensional portal with the help of the program ETABS 2013 version. This study is used to evaluate the feasibility of existing buildings or new building designs or referred to as redesign. SMK Al - Murqoniyah's building is designed with a reinforced concrete structure. The amount of reinforcement obtained from the analysis results for plate $(\mathrm{t}=120 \mathrm{~mm})$ reinforcement is used D10-100 reinforcement for each support and field, the beam structure uses 3D13 flexural reinforcement in the compressive area and 3D13 in the tensile area, with the stirrup distance on the supports is D10-100 in the area. supports and D10-150 in the field area, as well as for $(200 \mathrm{X} 400 \mathrm{~mm})$, column bending reinforcement 10D16 and D10-100 stirrups are used in the support area and D10-150 reinforcement in the field area. Based on the results of the analysis that has been carried out using the assistance of a structural analysis program, it can be stated that the structural elements of this building are safe in analysis and the structure of the Al-Murqoniyah Vocational School learning building has been planned according to the applicable design rules.
\end{abstract}

Keywords: Reinforced Concrete Structure, Redesign, Reinforcement Analysis

\section{Introduction}

School is an important means of improving human life and quality, especially in the quality of education for the nation's children. In it, there are learning and teaching activities for students by teachers in schools. One of the supporting factors for learning in schools is space for learning and a series of activities. The Al-Murqoniyah Vocational School is a private vocational high school located in Bogor Regency. Along with the need for study spaces that are in accordance with the capacity of students each year, it is planned to add new classrooms. For that, an analysis of the calculation of the structure of a new school building is needed to support learning activities at the Al-Murqoniyah Vocational School. This school previously had a 1 floor exsting structure that was used in teaching and learning activities. As time increases and prospective new students, the addition of new classrooms for the teaching and 
learning process will greatly assist academics in accommodating an increasing number of students, so that various kinds of material can be conveyed by the teacher while in the classroom. With the addition of classrooms at the second floor level in order to create a new learning atmosphere that will foster interest and create a learning spirit that is in accordance with the curriculum and effective and efficient learning methods.

The redesign of the Al-Murqoniyah Vocational High School is planned to be built on two floors which will function as classrooms, teachers' rooms, principal's room, and lab / practicum room for electronic engineering expertise program. The method used in its construction is using conventional methods with reinforced concrete material. Based on the above background, this research was conducted to design the structure of the SMK AlMurqoniyah school building which consists of 2 floors, the main material used is reinforced concrete. The results of this research are in the form of dimensions and reinforcement in accordance with the strength requirements set in SNI 1726-2012 concerning Earthquake Resistance Planning Procedures for Buildings and SNI 2847-2013 concerning Procedures for Planning Concrete Structures for Buildings.

\section{Literature Review}

\subsection{General}

All structural components must be planned strong enough in accordance with the provisions required in the [1] procedure. The load acting on a structure is caused directly by natural or human forces where there are two basic sources of building load, namely geophysical and man-made. structure is a means of transferring loads resulting from the use and / or presence of buildings on the ground [2]

The nature of the concrete material is very strong to withstand compression but not strong enough to withstand tensile, so that the concrete can experience cracks if the load it carries causes a tensile stress that exceeds its tensile strength. In order to withstand a sufficiently large tensile force on the lower edges of the beam fibers, reinforcing steel is necessary[3]. In a building construction, the column functions as a support for the loads from beams and plates, to be transmitted to the subgrade through the foundation [4]. Flat plate (flat plate) is a solid concrete plate with even thickness that transfers the load directly to the supporting column without the help of beams or column heads or drop panels [5].

\subsection{Structure Loading}

Provisions regarding planning in the procedure for [1] are based on the assumption that the structure is planned to bear the workload.

Based on the Indonesian Loading Regulations for Buildings of 1983 article 1 page 7 explains the definition of loading, including:

1. Dead load is the weight of all parts of a building that are fixed, including all additional elements, finishes, and equipment that are an integral part of the building.

2. Live loads are all loads that occur as a result of the use of a building and into it, including loads on the floor originating from the loads that can move, resulting in changes in floor and roof loading. Especially for roofs, live loads include rainwater loads caused by puddles and falling water droplets.

3. Wind load is all loads that work on the building or part of the building caused by differences in air pressure. 
4. Earthquake Load is all equivalent static load acting on a building or part of a building that mimics the effect of ground motion due to the earthquake. The effect of the earthquake on the building structure is determined based on a dynamic analysis

\subsection{Structural Rigidity}

According to Wolfgang Schueller structural rigidity [6] a rigid frame is a rigid connection used between linear structural arrangements to form a vertical and horizontal plane. A vertical plane consists of columns and beams, usually on a square grid.

\subsubsection{Main Factors and Risk Category Structure}

Article 4.1.2 [7] , for various risk categories for building and non-building structures according to table 2.1 the effect of the earthquake plan on them must be multiplied by the priority factor Ie. Especially for building structures with risk category IV, if an entrance is required for operations and an adjacent building structure, then the adjoining building structure must be designed in accordance with risk category IV.

Table 1 Building and non-building risk categories for earthquake loads

\begin{tabular}{lc}
\hline \multicolumn{1}{c}{ Type of Use } & Risk category \\
\hline Buildings and non-buildings designated as essential facilities, & \\
including, but not limited to: & \\
- Buildings - monumental buildings & IV \\
- School buildings and educational facilities & \\
- Hospitals and other health facilities that have surgical & \\
facilities and an emergency department & \\
- Fire fighting facility, ambulance and police station, as well \\
as emergency vehicle garage
\end{tabular}

\subsection{Reinforced Concrete Structures Design}

[1] concrete is a mixture of Portland cement or other hydraulic cement, fine aggregate, coarse aggregate and water, with or without additives that form a solid mass.

[1]reinforced concrete is reinforced concrete with an area and number of reinforcements not less than the minimum value, which is required with or without prestress, and is planned based on the assumption that the two materials work together to withstand the working forces.

\subsubsection{Design}

All components of reinforced concrete structures must be planned to be strong enough in accordance with the provisions required in the [1] standard on the procedure for calculating concrete structures for buildings, using the appropriate load factor and strength reduction factor $\varphi$.

\subsubsection{Modulus of Elasticity}

The modulus of elasticity of concrete and reinforcing steel is determined as follows:

1. For the value of wc between $1500 \mathrm{~kg} / \mathrm{m} 3$ and $2500 \mathrm{~kg} / \mathrm{m} 3$, the modulus of elasticity of Ec concrete can be taken as (wc) 1.5. $0.0043 \sqrt{ } f^{\prime} c(\mathrm{MPa})$.

2. For normal concrete, Ec can be taken as much as $4700 \sqrt{ } f^{\prime} \mathrm{c}$.

3. The modulus of elasticity for non-stressed reinforcement is taken to be $200000 \mathrm{MPa}$. 


\subsubsection{Provisions Regarding Strengths and Capabilities Self}

The load must have internal strength and resistance to various types of failures [8]. The structure must be planned so that all sections have a minimum design strength equal to the required strength, which is calculated based on a combination of load and factor forces (10).

\subsubsection{Strength Required}

The strength of a structural component or cross-section required to withstand a factored load or moment and the internal force associated with the load in a combination as specified in the SNI 2847-2013 procedure.

The necessary strength required in provision9.2.1 of SNI 2847-2013 are:

$\mathrm{U}=1.4 \mathrm{D}$

$\mathrm{U}=1,2 \mathrm{D}+1.6 \mathrm{~L}$

$\mathrm{U}=0.75(1,2 . \mathrm{D}+1,6 . \mathrm{L}+1,6 . \mathrm{W})$

$\mathrm{U}=0.9 . \mathrm{D}+1.3 . \mathrm{W}$

$\mathrm{U}=1.05(\mathrm{D}+0.6 . \mathrm{L}+\mathrm{E})$

$\mathrm{U}=0.9(\mathrm{D}+\mathrm{E})$

Where,

$\mathrm{D}=$ dead load,

$\mathrm{L}=$ live load,

$\mathrm{W}=$ wind load, and

$\mathrm{E}=$ earthquake load..

\subsection{Strength Plan}

The design strength of the structural components and their sections, with respect to their flexural behavior, normal loads, shear and torsion, shall be taken as the product of the nominal strength, which is calculated on the basis of the terms and assumptions of this procedure, with a strength reduction factor $\varphi$. The strength reduction factor $\varphi$ is determined as follows:

Moment of bending without axial force

$\varphi=0.90$ SNI 2847-2013 article 9.3.2.7

Tensile axial force, or moment with tensile force

$\varphi=0.90$ SNI 2847-2013 article 9.3.2.1

Compressive axial force, or moment with compressive force

$\varphi=0.75$ SNI 2847-2013 article 9.3.2.2

Shear force

$\varphi=0.75$ SNI 2847-2013 article 9.3.2.3

\section{Methods}

Structural design is a stage that must be carried out before the construction process takes place by referring to the regulations relating to the structure of multi-storey buildings so that the results are as expected. The flow diagram explains in detail the design of the building structure (11). 
In general, the method of designing the structure of the AL-Murqoniyah Vocational School building with the moment-bearer frame system is as follows:

\subsection{Data Collection}

a. The regulatory books, among others: SNI 1726 - 2012 concerning Procedures for Earthquake Resistance Planning for Buildings, SNI 2847-2013 concerning Procedures for Planning Concrete Structures for Buildings, and SNI 03 - 1727 - 1989 concerning Procedures for Indonesian Loading for Houses and Building.

b. Building Location

The building of SMK Al-Murqoniyah which is located on Jl. Tajur Tapos, RT 21/07 Kp. tajur tapos, Hambalang Village, kec. Citeureup, Kab. Bogor.

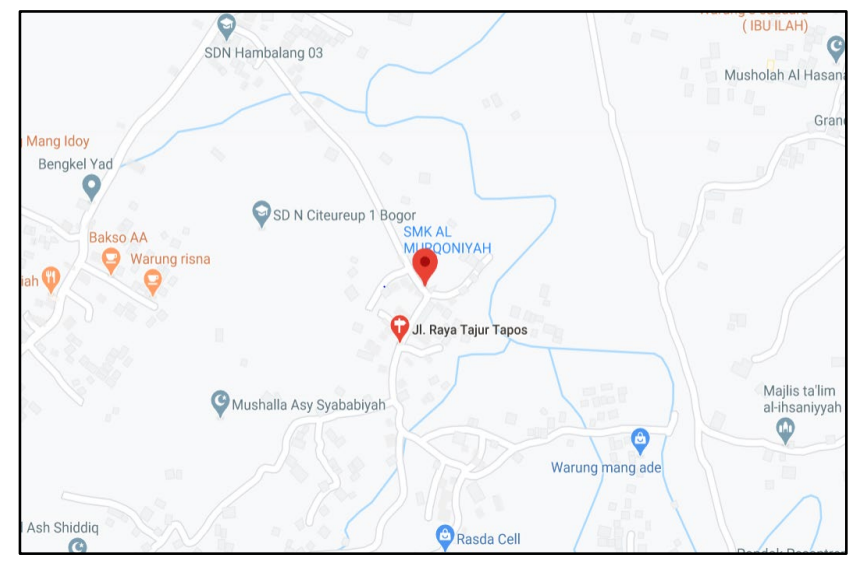

Figure 1. Location of SMK Al-Murqoniyah

\subsection{Building Technical Data}

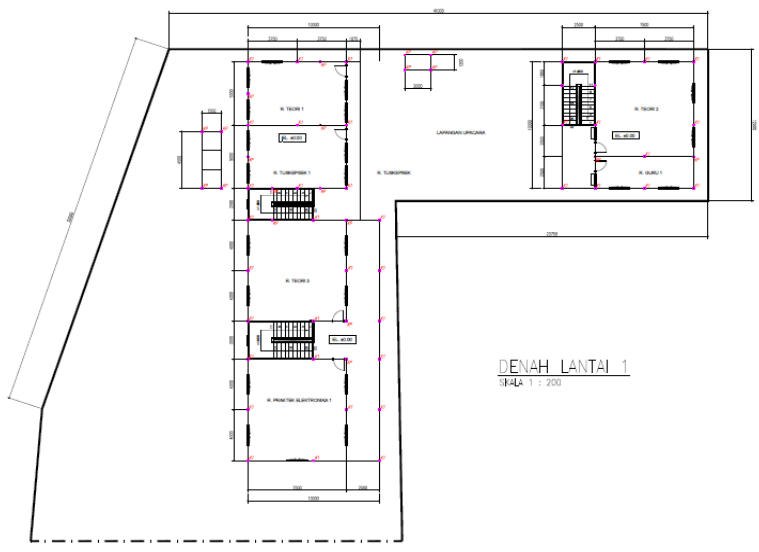

Figure 2. Building Floor of SMK Al-Murqoniyah Number of Floors: 1 Existing Floor

Type of Construction: Reinforced concrete 
Concrete Quality: K225

Reinforcement Quality:

Reinforcement D = 13: U40 steel ( fy $=390 \mathrm{MPa}$ )

Reinforcement $\mathrm{D}=10$ : $\mathrm{U} 24$ steel $(\mathrm{fy}=240 \mathrm{MPa})$

Steel Grade: BJ37

\subsection{Design Code and Standard}

a. American Concrete Institute (ACI 318-99)

b. SNI 2847-2013 Tata Cara Perencanaan Struktur Beton untuk Bangunan Gedung

c. Peraturan Pembebanan Indonesia untuk Gedung (PPIUG) -1983

d. SNI 1726-2012 Tata Cara Perencanaan Perencanaan Gempa untuk BangunanGedung.

e. SNI 1729-2002 Tata Cara Perencanaan Struktur Baja untuk Bangunan Gedung..

\subsection{Program / Software}

a. ETABS Versi 9.7.4

b. PCACOL

c. Spreadsheet Excel

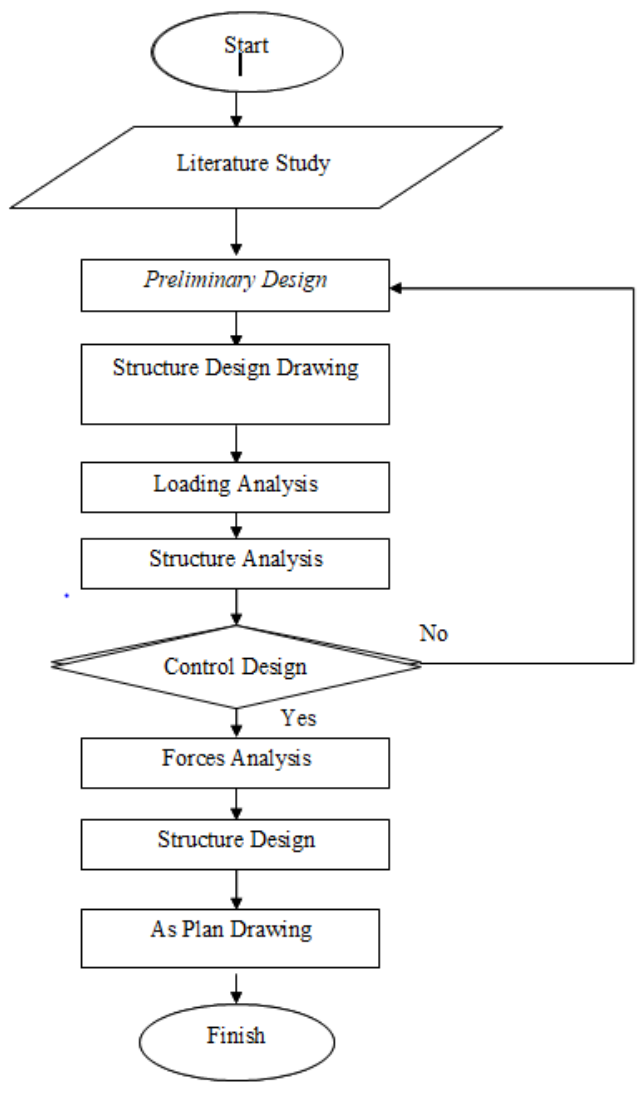


Figure 3. Design Flow Chart

\section{Result and Discussion}

In the analysis, the loading system that will be charged to the building is a horizontal loading system that includes earthquake and wind loads, and vertical loading includes live and dead loads, both the structure's own weight and additional dead loads as a result of using the building [9].

\subsection{Load}

1. Dead Load [10][11](DL)

Dead load is the structure's own weight
1. Density of concrete

$$
=2400 \mathrm{~kg} / \mathrm{m} 3
$$
2. wall weight

$$
=150 \mathrm{~kg} / \mathrm{m} 2
$$

2. Additional Dead Load Floor
1. Ceiling
$=18 \mathrm{~kg} / \mathrm{m} 2$
2. Ceramic $1 \mathrm{~cm}$ thick $=25 \mathrm{~kg} / \mathrm{m} 2$
3. Finishing $3 \mathrm{~cm} \quad=66 \mathrm{~kg} / \mathrm{m} 2$
4. $\mathrm{ME}$
$=20 \mathrm{~kg} / \mathrm{m} 2$

3. Additional Dead Load Stairs
1. Ceramic $1 \mathrm{~cm}$ thick
$=22 \mathrm{~kg} / \mathrm{m} 2$
2. Species + tiles $5 \mathrm{~cm}$ thick $=110 \mathrm{~kg} / \mathrm{m} 2$
3. Stair railing $\quad=10 \mathrm{~kg} / \mathrm{m} 2$
4. Dinding $1 / 2$ Bata $=250 \mathrm{~kg} / \mathrm{m} 2$

4. Live Load [11] (LL)

Live load for the school floor is $250 \mathrm{~kg} / \mathrm{m} 2$

Live load for staircase is $300 \mathrm{~kg} / \mathrm{m} 2$ 2012)

Structure analysis of earthquake loads refers to SNI Earthquake Regulation (SNI 1726-

The analysis was performed using the Equivalent Static Method. The determination of the earthquake force uses the spectra design parameters which are taken online from the puskim.go.id website [12].

Building Risk Category, KDRB : Category IV

Earthquake Priority Factors,

Ie : 1,5

Ground Acceleration parameters

Ss : 1,0434

$\mathrm{S}_{1}: 0,4762$

Kelas Situs

SE : (soft soil)

Faktor Koefisien Situs

Fa : 0,9

FV $: 2,4$

Seismic Design Category

Category: KDS D

Structure system:

Moment Bearer Frame 


\subsection{Design Spectral Acceleration Parameters}

The response parameters of acceleration spectral for maximum earthquake that have been adjusted class and site coefficient :

$$
\begin{array}{rl}
S_{m s} & =F a \cdot S s \\
& =0,9 \cdot 1,0434 \\
& =0,93906 \\
S_{M 1} & =F v \cdot S_{1} \\
& =2,4 \cdot 0,4762 \\
& =1,14288 \\
S_{D S} & =\frac{2}{3} \cdot S_{M S} \\
& =\frac{2}{3} \cdot 0,93906 \\
& =0,62604 \\
& =\frac{2}{3} \cdot 1,14288 \\
S_{D 1} & 0,76192
\end{array}
$$

\subsection{Equivalent Lateral Static Force}

The parameter for static earthquakes are :

$$
\begin{aligned}
\mathrm{T}_{\mathrm{a}} & =\mathrm{C}_{\mathrm{t}} \cdot \mathrm{h}_{\mathrm{n}} \mathrm{x} \\
& =0,0466 \cdot 8,6^{0,9} \\
& =0,32317 \\
\mathrm{~T} & =\text { Cu.Ta } \\
& =1,4 \cdot 0,32317 \\
& =0,45243
\end{aligned}
$$

In the ETABS program, building periode for $\mathrm{x}$ and $\mathrm{y}$ is $\mathrm{Tx}=\mathrm{Ty}=1,12665$ seconds, because $T a<\mathrm{Tc}<\mathrm{Cu}$.Ta, the building periode has static limit periode limit requirements. The response acceleration parameter (SDS) depends on the earthquake area and the type of soil where the structure is planned, while the load size (W) is the total dead load of the building structure [13].

Table 2 Static Analysis Calculations

\begin{tabular}{c|c|c|c|c|c}
\hline Story & HI & $\mathbf{W i}$ & $\mathbf{K}$ & $\mathbf{W i H i}^{\wedge} \mathbf{k}$ & $\mathbf{C v}$ \\
\hline & $\mathbf{M}$ & $\mathbf{K g}$ & & $\mathbf{k g f - m}$ & \\
\hline STORY2 & 8,6 & 11801,28 & 1,31 & 199171,64 & 0,75 \\
\hline STORY1 & 3,8 & 11238,29 & 1,31 & 64884,84 & 0,25 \\
\hline TOTAL & 12,4 & 23039,57 & 2,62664596 & 264056,4839 & 1 \\
\hline
\end{tabular}

\subsection{Seismic Base}




$$
\begin{aligned}
& C_{s} \quad=\frac{S_{D S}}{\left(\frac{R}{I_{e}}\right)} \\
&=\frac{0,62604}{\left(\frac{8}{1,5}\right)} \\
&=0,117383 \\
& C_{s} \quad \frac{S_{D 1}}{T\left(\frac{R}{I_{e}}\right)} \\
&<\frac{0,76192}{1,126646\left(\frac{8}{1}\right)} \\
&<0,126801 \\
& \text { Cs } \quad>0,044 . S_{D S} I_{e} \\
& \quad>0,044.0,117383.1,5
\end{aligned}
$$

Based on the Cs value above, the Cs value is 0,05

$$
\begin{aligned}
\mathrm{V}_{(\mathrm{x}, \mathrm{y})} & =\mathrm{C}_{\mathrm{s}} \cdot \mathrm{W}_{\mathrm{t}} \\
& =0,126801.23039,5699 . \\
& =2921,443889 \mathrm{~kg}
\end{aligned}
$$

Table 3 Result of Slab Structure Design Analysis

\begin{tabular}{ccccc}
\hline Reinforcement & Axis & $\begin{array}{c}\text { Momen } \\
\mathbf{( N m m )}\end{array}$ & $\begin{array}{c}\text { As } \\
\left(\mathbf{m m}^{2}\right)\end{array}$ & $\begin{array}{c}\text { reinforcement } \\
\text { attached }\end{array}$ \\
\hline \multirow{2}{*}{ Support } & $\mathrm{X}$ & 5701000 & 549,5 & $\mathrm{D} 10-150$ \\
\cline { 2 - 5 } & $\mathrm{Y}$ & 3899000 & 549,5 & $\mathrm{D} 10-150$ \\
\hline \multirow{2}{*}{ Filed } & $\mathrm{X}$ & 4042000 & 549,5 & $\mathrm{D} 10-150$ \\
\cline { 2 - 5 } & $\mathrm{Y}$ & 3290500 & 549,5 & $\mathrm{D} 10-150$ \\
\hline
\end{tabular}

Table 4 Result of Beam Structure Design Analysis

\begin{tabular}{ccccccc}
\hline \multirow{2}{*}{ Beam } & Support & Support & Filed & Filed & Support & Filed \\
Type & Top & Bottom & Top & Bottom & Shear & Shear \\
& Rebar & Rebar & Rebar & Rebar & Reinforcement & Reinforcement \\
\hline
\end{tabular}




\begin{tabular}{lllllll}
\hline B200X400 & 3D13 & 3D13 & 3D13 & 3D13 & D10-100 & D10-150 \\
\hline B200X300 & 2D13 & 2D13 & 2D13 & 2D13 & D10-100 & D10-150 \\
\hline
\end{tabular}

Table 5 Result of Column Structure Design Analysis

\begin{tabular}{c|c|c|c}
\hline Column & $\begin{array}{c}\text { Longitudinal } \\
\text { Rebar }\end{array}$ & $\begin{array}{c}\text { Support } \\
\text { Shear } \\
\text { Reinforcement }\end{array}$ & $\begin{array}{c}\text { Filed } \\
\text { Shear } \\
\text { Reinforcement }\end{array}$ \\
\hline K200X250 & $10 \mathrm{D} 16$ & $\mathrm{D} 10-100$ & $\mathrm{D} 10-150$ \\
\hline $\mathrm{K} 150 \mathrm{X} 150$ & 4D16 & $\mathrm{D} 10-100$ & $\mathrm{D} 10-150$ \\
\hline
\end{tabular}

\section{Conclusions}

Based on the results of the analysis and calculations that have been carried out in the redesign of the learning room development of the Al-Murqoniyah Vocational School, Hambalang, it can be concluded that the number of reinforcement obtained from the analysis results for plate reinforcement $(\mathrm{t}=120 \mathrm{~mm})$ is used D10-150 reinforcement for each for each pedestal and field, the beam structure $(200 \mathrm{X} 400 \mathrm{~mm})$ is used 3D13 bending reinforcement in the compressive area and 3D13 in the tensile area, with the spacing of the spacing on the pedestal is D10-100 in the bearing area and D10-150 in the field area, as well as for column bending reinforcement (200X250 $\mathrm{mm}$ ) used 10D16 reinforcement and D10-100 stirrups in the support area and D10-150 reinforcement in the field area. Based on the results of the analysis that has been carried out using the assistance of a structural analysis program, it can be stated that the structural elements of this building are safe in analysis and the structure of the Al-Murqoniyah Vocational School learning building has been planned according to the applicable design rules, which are regulated in SNI 1726-2012 concerning Procedures. Earthquake Resistance Planning for Buildings and SNI 2847 2013 concerning Planning Procedures for Concrete Structures for Buildings.

Based on the analysis that has been carried out, there is a need for improvements through several suggestions as follows. It is necessary to take into account the analysis of the substructure, namely the foundation. This is because the conditions of the Covid-19 pandemic have made implementation not progressing properly resulting in the absence of land data in processing data and conducting analysis, it is necessary to have a further review of foundation planning, namely by carrying out soil investigations on site.

\section{Reference}

[1] B. S. Nasional, "SNI 03-2847-2013 Tata cara Perhitungan Struktur Beton Untuk Bangunan Gedung," Jakarta Badan Stand. Nas., 2013.

[2] D. L. Schodek, D. Subagdja, and B. Suryoatmono, Struktur. Erlangga, 1999.

[3] A. Asroni, "Balok dan pelat beton bertulang," Yogyakarta Graha Ilmu, 2010.

[4] A. Asroni, "Kolom Fondasi dan Balok T Beton Bertulang," Yogyakarta Graha Ilmu, 2010.

[5] A. AZLAMNI, "STUDI PERANCANGAN STRUKTUR GEDUNG HOTEL GOLDEN TULIP DENGAN MENGGUNAKAN SISTEM PELAT LANTAI DATAR (FLAT PLATE).” UNIVERSITAS MUHAMMADIYAH MATARAM, 2020. 
[6] W. Schueller, The vertical building structure. Van Nostrand Reinhold, 1990.

[7] B. S. Nasional, "SNI 03-1726-2012 Tata Cara Perencanaan Ketahanan Gempa Untuk Bangunan Gedung," Jakarta BSN, 2012.

[8] E. G. Nawy, T. Surjaman, and B. Suryoatmono, Beton Bertulang: Suatu Pendekatan Dasar. PT. Eresco, Bandung, 1990.

[9] E. Honggo, M. Yusuf, and A. Supriyadi, "Perhitungan Struktur Hotel 11 Lantai Jalan Teuku Umar Pontianak.” Tanjungpura University, 2015.

[10] B. S. Nasional, "Pedoman Perencanaan Pembebanan untuk Rumah dan Gedung," BSN, Jakarta, 1989.

[11] "Beban minimum untuk perancangan bangunan gedung dan struktur lain Badan Standardisasi Nasional,” 2013.

[12] B. Baehaki, S. Soelarso, and S. Subandi, "Redesign Struktur Balok pada Gedung Kuliah FT. UNTIRTA berdasarkan SNI 1726-2012 dan SNI 2847-2013,” Tek. J. Sains dan Teknol., vol. 15, no. 1, pp. 13-22, 2019.

[13] M. I. Zidny, W. A. Widiyanto, I. Nurhuda, and H. Indarto, "Perencanaan Struktur Gedung Politeknik Kesehatan Semarang,” J. KARYA Tek. SIPIL, vol. 4, no. 4, pp. 362-370, 2015. 